\title{
DOI https://doi.org/10.30525/978-9934-26-179-4-6
}

\section{СПРАВЕДЛИВІСТЬ І ЗАКОННІСТЬ: ПРОБЛЕМИ СПІВВІДНОШЕННЯ}

\author{
Романенко Ю. С. \\ студентка I курсу магістратури \\ Інститут права
}

Київського наиіонального університету імені Тараса Шевченка м. Київ, Україна

«Справедливість» і «законність», - дискусії щодо співвідношення цих двох понять не вщухають вже багато століть.

Питанням з'ясування природи справедливості та законності у своїх роботах займались такі вітчизняні та зарубіжні науковці, як: П.С. Берзін, В.О. Гацелюк, О.О. Дудоров, С.Г. Келіна, Т. Н. Добровольська, А. М. Колодій, В. Т. Маляренко, М. М. Михеєнко, В. Т. Нор, А. Л. Рівлін, В. Я. Тацій, В. М. Тертишник, В. П. Шибіко та інші.

Слово «справедливо» ми вперше чуємо і намагаємось зрозуміти ще в дитинстві. Приблизно тоді, коли вчимось розділяти такі моральні категорії, як: добро і зло, свобода, совість, щастя, обов'язок і т.п. Цікавий парадокс: чим старшою стає людина, тим складніше i неоднозначніше вона сприймає ці поняття. Так, знання, які людина прямо чи опосередковано здобуває впродовж життя накладають відбиток на ії розуміння таких простих, здавалося б, слів, адже з часом, вона усвідомлює, що всі категорії, так чи інакше пов'язані з мораллю, $\epsilon$ доволі суб' єктивними.

Інша справа - законність. Якщо поняття, які згадувались мною вище, ми вперше зустрічаємо в дитячих казках і мультиках, то останне - в новинах. Варто також зазначити, що доволі довгий час люди не вглиблюються в суть слова «законність», не намагаються зрозуміти його сенс. $\mathrm{y}$ більшості випадків вони починають грунтовно знайомитись 3 ним на курсі «Право» в школі. I саме тоді можна вперше помітити, як часто «законність» і «справедливість» фігурують в одному контексті. На мою думку, саме тоді ми робимо перший крок до вирішення і з'ясування, перш за все, для себе, проблем співвідношення цих двох понять.

Переважно, досліджувані категорії, виступають принципами права, тобто незаперечними вимогами, які йому властиві і без яких воно не може існувати. Не можна не помітити, що принцип законності i 
принцип справедливості ні в якому разі не ототожнюються, а виступають окремо, та все ж не рівні в своїй важливості.

Формування сутності та змісту принципу справедливості бере початок ще $з$ періоду Давнього Риму, про що свідчать висловлювання тогочасних юристів. Так, вони стверджували, - «коли відсутній чіткий правовий припис, бажано справу вирішувати по справедливості, а також «коли право суперечить справедливості, повинна панувати остання». Тож, римські юристи, певною мірою, ставили справедливість вище за законність; вважали, що правовий припис (що можна розуміти як закон), суперечачи справедливості, не може виконуватись і застосовуватись.

Принцип законності, як категорія, був сформований значно пізніше. Навідміну від першого, що більшою мірою стосується моральних суб’єктивних переконань, останній є вимогою чіткої визначенності до самої норми, до їі, так би мовити, форми. Мається на увазі те, що норма права, обмежуючи, покладаючи певний обов'язок, тощо - повинна встановлювати конкретні межі, де немає місця для суб'єктивного трактування.

Не менш часто можна зустріти питання співвідношення справедливості і законності в контексті судового рішення. Річ у тім, що будь-яке рішення суду має бути законним (за звичаєм як законом неписаним або за офіційним законом), й водночас справедливим (тобто розумним, співрозмірним). Водночас вважається, що бути справедливим суддею - це не тільки знати закони, а й мати справедливість за мету власного життя, для якого захист справедливості є найважливішим.

Окрім того, варто згадати переконання Платона - прагнення до ідеалу, хай навіть і об'єктивно недосяжного, дасть суспільству набагато більше, ніж примирення 3 відвертою недосконалістю. Так, законна справедливість і справедливий закон - ідеали, до яких необхідно рухатись. На жаль, часто на практиці трапляється так, що закон не є справедливим, i перед судом часто постає питання: керуватись принципом законності чи справедливості? Чи можна зробити вийняток iз закону, керуючись принципом справедливості? Чи таке виключення 3 правил потягне за собою нові порушення і Закон $є$ Закон для всіх, незалежно від обставин справи?

Звідси постає питання, чи можливо створити такий закон, який був би справедливим для всіх без винятку? На мою думку, це навряд чи можливо, а отже, скоріш за все, дискусії з цього питання триватимуть вічно.

Відповідно, наблизитись до ідеалу можна лише розглядаючи кожний випадок індивідуально, окремо враховуючи обставини конкретної справи. Не завжди законне рішення є справедливим, а справедливе - законним. Нерідко одне повністю виключає інше. Але ж 
хіба справедливість - це не те, що потрібно захищати понад усе? На моє переконання, відповідь очевидна. Як влучно зазначав у свій час персидський поет Мухаммед Аззахірі ас-Самарканді, основи кожної держави й фундамент будь-якої країни спочивають на справедливості та правосудді.

\section{Література:}

1. Булгаков В. В. Концепция справедливости в прав е: автореф. дис. на ... канд. юрид. наук: спец. 12.00.01 «Теорія та історія держави і права. Історія політичних вчень». Белгород, 2002. С. 8.

2. Джентиле $\Phi$. О роли философии права в изучении юриспруденции в Италии. Государство и право. 1995. № 1.

3. Лейст О.Э. Сущность права. Проблемы теории и философии права. М. : Зерцало-М, 2002. 288 с. С. 170.

4. Нерсесянц В.С. Философия права : ученик. 2-е изд., перераб. и доп. М. : Норма, 2009. 848 с. С. 46.

5. Погребняк С.П. Основоположні принципи права (змістовна характеристика) : монографія. Х. : Право. 240 с. С. 37.

6. Ролз Дж. Теория справедливости : пер с англ. / науч. ред. и пред. В.В. Целищева. Изд. 2-е. М. : Изд-во ЛКИ, 2010. 536 с. С. 25-30.

7. Циппеліус Р. Філософія права: пер. 3 нім. К. : Тандем, 2000. 300 c. C. $41-42,46$.

8. Хёффе О. Политика. Право. Справедливость: основоположения критической философии права и государства / пер. с нем. Вл. С. Малахова при участии Е. В. Малаховой. М., 1994.

9. Тимошина Е. В. Право как справедливость: концепция интуитивного права в школе Л. И. Петражицкого. Правоведение. 2010. № 6. С. 179-195. 